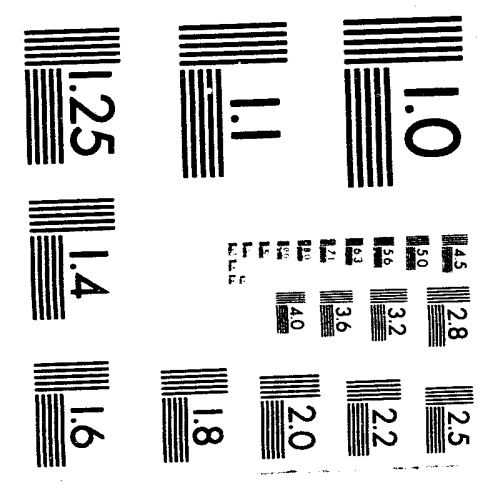



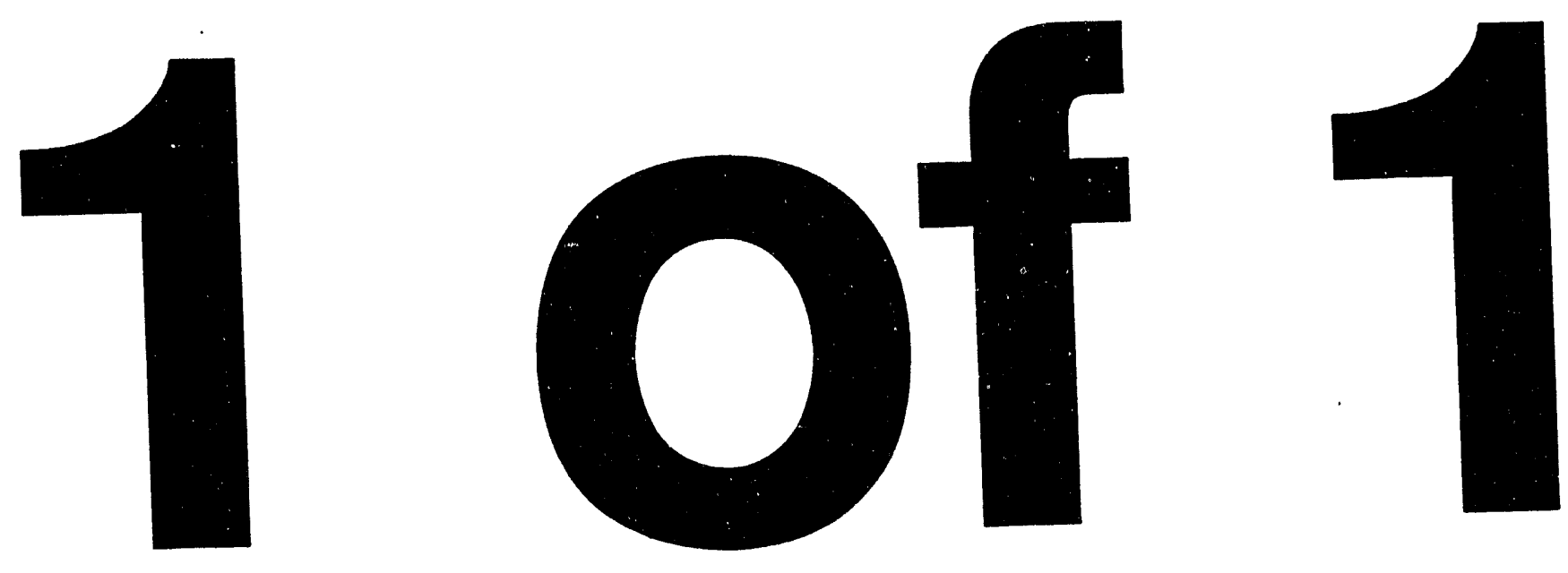


\section{NUCLEAR MATERIALS MANAGEMENT STORAGE STUDY (U)}

by

G. W. Becker, Jr.

Westinghouse Savannah River Company

Savannah River Site

Aiken, South Carolina 29808

This paper was prepared in connection with work done under the above contract number with the U. S.

Department of Energy. By acceptance of this paper, the publisher and/or recipient acknowledges the U. S. Government's right to retain a nonexclusive, royalty-free license in and to any copyright covering this paper, along with the right to reproduce and to authorize others to reproduce all or part of the copyrighted paper. 


\title{
PREDECISIONAL
}

\section{UNCLASSIFIED SUMMARY NUCLEAR MATERIALS MANAGEMENT STORAGE STUDY (U)}

February 1994

Planning Support Group

\author{
UNCLASSIFIED \\ DOES NOT CONTAIN \\ UNCLASSIFIED CONTROLLED \\ NUCLEAR INFORMATION
}

ADC/Reviewing Official:

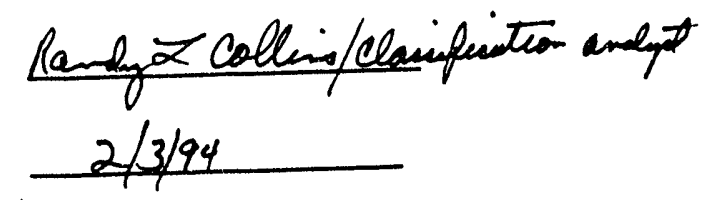

Date:

Prepared for the U.S. Department of Energy under Contract DE-AC09-89SR18035

Managed by Westinghouse Savannah River Company Planning Division 


\section{DISCLAIMER}

This report was prepared as an account of work sponsored by an agency of the United States Government. Neither the United States Government nor any agency thereof, nor any of their employees, makes any warranty, express or implied, or assumes any legal liability or responsibility for the accuracy, completeness, or usefulness of any information, apparatus, product, or process disclosed, or represent that its use would not infringe privately owned rights. Reference herein to any specific commercial product, process, or service by trade name, trademark, manufacturer, or otherwise does not necessarily constitute or imply its endorsement, recommendation, or favoring by the United States Government or any agency thereof. The views and opinions of authors expressed herein do not necessarily state or reflect those of the United States Government or any agency thereof. 


\title{
PREDECISIONAL
}

\section{NUCLEAR MATERIALS MANAGEMENT STORAGE STUDY (U) UNCLASSIFIED SUMMARY}

\author{
George W. Becker, Jr. \\ Planning Support Group \\ Westinghouse Savannah River Company
}

February 1994

APPROVED BY:

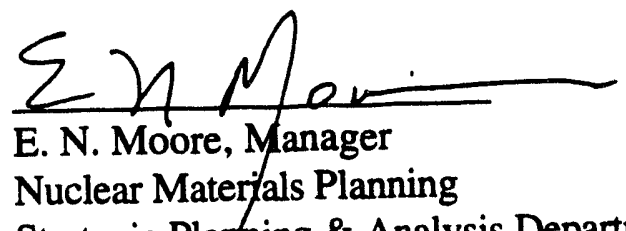

Strategic Planning \& Analysis Department 


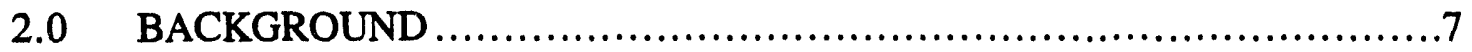

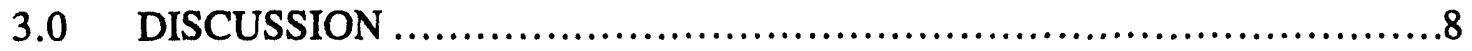

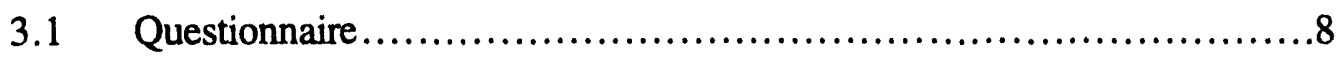

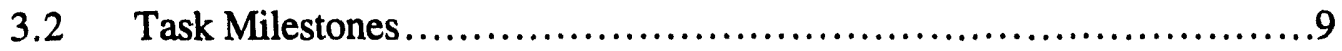

3.3 Storage Study Database ................................................

3.4 Initial Summary of Storage Issues and Concerns........................9

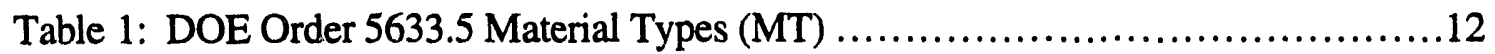

Table 2: Storage Study Milestones...............................................13

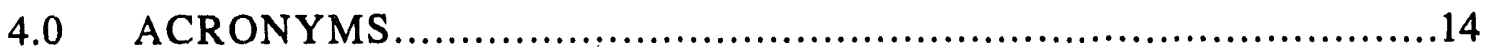

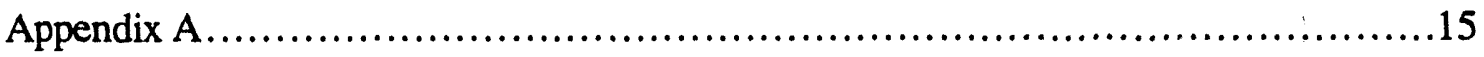


NMP-94-01 


\subsection{INTRODUCTION/SUMMARY}

The Office of Weapons and Materials Planning (DP-27) requested 1.2 the Planning Support Group (PSG) at the Savannah River Site to help coordinate a Departmental complex-wide nuclear materials storage study. This study will support the development of management strategies and plans until Defense Programs' Complex 21 is operational by DOE organizations that have direct interest/concerns about or responsibilities for nuclear material storage. They include the Materials Planning Division (DP-273) of DP-27, the Office of the Deputy Assistant Secretary for Facilities (DP-60), the Office of Weapons Complex Reconfiguration (DP-40), and other program areas, including Environmental Restoration and Waste Management (EM).

To facilitate data collection, a questionnaire was developed and issued to nuclear materials custodian sites soliciting information on nuclear materials characteristics, storage plans, issues, etc. (see Appendix A). Sites were asked to functionally group materials identified in DOE Order 5660.1A (Management of Nuclear Materials) based on common physical and chemical characteristics and common material management strategies and to relate these groupings to Nuclear Materials Management Safeguards and Security (NMMSS) records. A database was constructed using 843 storage records from 70 responding sites. The database $e^{3,4,5}$ and an initial report ${ }^{6}$ summarizing storage issues were issued to participating Field Offices and DP-27 for comment.

This report presents the background for the Storage Study and an initial, unclassified summary of storage issues and concerns identified by the sites. A classified version of this report (NMP-94-02), containing the complete Storage Study database and classified details supporting the initial summary, has been provided to a limited distribution. Both reports have incorporated the responses and comments from the Operations Offices and their contractors.

\subsection{BACKGROUND}

The DOE manages and uses a wide range of nuclear materials (listed in Table 1) that have (or could have) defense applications or have use outside of the defense complex in medical, research, industrial, and commercial uses. DOE's Office of Weapons and Materials Planning (DP-27) is responsible for the administration of the Department's nuclear materials management program.

Letter, C. G. Haisted to C. C. Mason, Nuclear Materials Management Study, September 15, 1992.

Letter, C. C. Mason to G. A. Krist, Nuclear Materials Study, September 28, 1992.

Report, G. W. Becker, Jr. et. al., Nuclear Materials Management Storage Study: Database Report, NMP-93-07, Rev. 1, June 14, 1993.

4 Report, G. W. Becker, Jr. et. al., Nuclear Materials Management Storage Study: Database Report, NMP-9307, Rev. 1, Addendum 1, July 1993.

5 Report, G. W. Becker, Jr. et. al., Nuclear Materials Management Storage Study: Special Database Report, NMP-93-12, August 1993.

6 Report, G. W. Becker, Jr. et. al., Nuclear Materials Management Storage Study: Draft Analysiss, NMP-93-13, September 1, 1993. 


\section{NMP-94-01}

It is unlikely that Defense Programs facilities will continue to produce many of these materials. Thus, it is prudent that reserve inventories of these materials be established and maintained for future defense and/or non-defense needs because of their innate values and other potential applications.

A comprehensive study addressing management options/actions for the storage of existing nuclear material inventories is needed because of:

- DOE's increased emphasis on efficient management and disposition of nuclear materials;

- increased internal and external interests in ascertaining the quantities and characteristics (chemical, isotopic, RCRA, etc.) of existing nuclear material inventories, the availability of existing and proposed storage capacities and capabilities, and the operability and availability of processing/treatment facilities;

- DOE's need to identify future resource requirements;

- regulatory issues with storage, processing/treatment, shipping, and disposition of inactive nuclear materials;

- concerns about excess nuclear materials identified in other Department sponsored studies (e.g. plutonium disposition studies); and

- the need to support nuclear materials de-inventory activities at individual sites and Defense Complex Reconfiguration plans.

Management issues, such as continued storage versus disposal, are arising from recent DOE mission changes that are causing closures of DOE facilities, decreasing programmatic demands for nuclear materials, expected increasing costs of managing nuclear materials, and budget reductions. The availability of safe, secure storage for the nuclear materials, required recovery or stabilization capabilities, potential utility of nuclear materials in their existing forms, and their value to industry all have a bearing on decisions for continued storage versus disposal. For some nuclear materials, existing storage may be inadequate and require upgrading to comply with established requirements. In some cases, materials may require relocation for disposition or storage. Thus, transportation and storage site location become issues. Required facilities for recovery/stabilization may be lacking, shutdown, or in need of upgrade. Identification and analysis of these issues will assist the DOE in evaluating the options, needs for, and priority of management actions. This storage study provides an initial part of the information and analysis that will be needed to address these nuclear materials management issues.

\subsection{DISCUSSION}

\subsection{Questionnaire}

A questionnaire was used to survey nuclear material production and processing sites and laboratories across the DOE complex on their nuclear material storage status, plans and issues. A Storage Study Questionnaire design meeting was sponsored by DP-27 and held at DOE Headquarters in Germantown, Maryland on January 27-28, 1993. The meeting objective was to support the Nuclear Materials Management Storage Study by addressing 
each site's specific issues/concerns regarding their nuclear material inventories, storage capacity and capability, and processing capability and availability, and to formally document this information into the form of a questionnaire. Meeting attendees, the resultant Storage Study Questionnaire, and DP-27's cover letter to Field/Operations Offices initiating the survey are attached in Appendix A.

Sites were asked to functionally group materials based on common physical and chemical characteristics and common material management strategies and to relate these groupings to Nuclear Materials Management Safeguards and Security (NMMSS) records. In addition to material and storage location descriptions for site specific "functional" material group, the Questionnaire solicited additional information such as

- Are facilities and forms adequaie for interim storage (50 years)?

- What are plans for the subject materials?

This required sites to develop additional technical and materials management information not contained in existing nuclear material accounting databases.

\subsection{Task Milestones}

Key Storage Study milestones are listed in Table 2.

\subsection{Storage Study Database}

Results from the Storage Study Questionnaire are contained in the classified Storage Study Database document (NMP-94-02). In NMP-94-02, 843 storage records from 70 respondents are sorted by

- Site,

- Material Type, and

- Site's individual record quantity.

\subsection{Initial Summary of Storage Issues and Concerns}

An initial summary of issues and concerns identified in the Storage Study follows. They were developed by surveying and synthesizing the database records for administrative, capacity, container, D\&D, disposition, form, health physics, RCRA, shipping, and inactive material storage issues and concerns. The classified version of this report contains a separate appendix with details supporting the initial summary.

- Changes in Facility Missions. Many nuclear materials were placed in shortterm or in-process storage when production processes were operating. New Program drivers, such as decontaminatiou and decommissioning of unneeded facilities or reconfiguration and restructuring of needed facilities, will require that many nuclear materials be relocated for long-term interim storage. Currently, many items exist in inappropriate forms for interim storage or in containers not intended for interim storage. In some cases inactive materials may need to be processed for stabilization and repackaged for continued storage 
prior to facility decommissioning. Storage concerns typically involved deinventoring of stored items on externally driven schedules.

- Reduced Multi-Site Integration. Historically many sites have shipped nuclear materials to other DOE sites for processing and storage. Some of these sites and facilities are no longer able to perform these functions.

- Change in Demand. Reduced missions, declining budgets, and increased costs have lowered the need for larger inventories. Many sites are seeking to reduce their inventories, often as a result of decisions to shut down facilities. Some materials with no current or future planned uses have been in storage for up to twenty years. In many cases, funding for materials disposition is not identified in program budgets.

- Impediments to Action. Even if sites have identified sound technical solutions to storage problems, the implementation is drawn out by the need for detailed and external review of plans and facilities. Typically the administrative issues were about required funding, safety/environmental assessments, operational readiness reviews, justification for continued operation, or DOE concurrence to alleviate a particular storage problem.

- Unstable Forms. Some of the inventories are not suitable for interim storage, because of radiological and chemical concerns. In general, these materials may be unstable, generate off-gas, and/or are corrosive and will require stabilization for shipping, continued storage, or disposal. The treatments required to stabilize these forms for storage or disposal are not readily available or defined.

- Health Protection Concerns. In general, these involve interim storage of materials exhibiting high radiation, reactivity, criticality, and high ingestion/inhalation dose potential.

- Regulatory Concerns. Many materials contain both hazardous as well as radioactive components. As a consequence of mission changes, some of these will or have become mixed wastes as defined by RCRA. In general, RCRA issues concern storage of materials containing corrosive (e.g., acid solutions), reactive (e.g., sodium), EP Toxicity (e.g., contain $\mathrm{Cd}, \mathrm{Cr}$, and $\mathrm{Ni}$ ), and ignitable materials (e.g., sodium or potassium). Other materials are exempt from RCRA under the Atomic Energy Act because they are product material. However, based on recent trends RCRA coverage will be broadened to include exempt materials under the speculative accumulation rule (when the material has reached the end of its useful life). This would have major impacts on management of the Department 's inactive nuclear material.

- Shipping Impediments. In general, these involve material items requiring treatment, overpacking, and/or repackaging for shipment. Shipping container availability is also a concern and a major impediment to inventory consolidation. 
- Disposition Uncertainties. There are many items for which disposition plans are uncertain due to the lack of material characterization, treatment/stabilization capability and availability, storage capacity, or the availability of shipping containers and required packaging.

- Container Concerns. Typically, container issues include adequacy of design for interim storage or the potential for loss of containment due to pressurization, corrosion, or degradation of the containment seals due to age.

- Capacity. Most sites have storage facilities that are either approaching capacity, full, need replacement due to age, will not be available in the future due to expected site and/or facility decontamination and decommission, or have limited overall capacity.

- Data Set Completeness Follow-up will be required to clarify questionnaire responses from several sites. Some sites functionally grouped materials at too high a level and their resulting responses to key storage questions were too general. Some sites with significant quantities of nuclear materials did not respond to the survey. Reporting facility names and NMMSS reporting identification symbols (RIS) of the major sites not included in the database are listed below.

$\begin{array}{ll}\text { RIS } & \text { Site } \\ \text { AAA } & \text { US DOE Albuquerque Field Office } \\ \text { FBF } & \text { Oak Ridge Associated Universities } \\ \text { FCW } & \text { Babcock \& Wilcox, Naval Nuclear Fuel Division } \\ \text { FTA, CMC } & \text { RMI Co, Extrusion Plant } \\ \text { KAS } & \text { Nuclear Fuel Services Inc. } \\ \text { KDS } & \text { UNC Naval Products } \\ \text { LAG } & \text { Sandia National Laboratory, Livermore } \\ \text { NAB } & \text { US DOE Nevada Test Site } \\ \text { PAA } & \text { US DOE Pittsburgh Naval Reactors Office } \\ \text { PCR } & \text { Babcock \& Wilcox Naval Nuclear Fuels } \\ \text { PZB } & \text { Westinghouse Bettis, Idaho } \\ \text { RFR,RGE, RUK } & \text { Foreign, Office of Safeguards \& Security } \\ \text { XHK } & \text { Allied-General Nuclear Services } \\ \text { YBC } & \text { National Institute of Standards \& Technology } \\ \text { YVB } & \text { Public Service Co of Colorado, Fort St. Vrain } \\ \text { ZZZF, ZZZL } & \text { Licensee Lease (Domestic, Foreign) }\end{array}$


Table 1: DOE Order 5633.5 Material Types (MT)

\begin{tabular}{|l|c|l|c|}
\hline NUCLEAR MATERIAL & MT & NUCLEAR MATERIAL & MT \\
\hline Depleted Uranium & $11-18^{\mathrm{a}}$ & Plutonium-239 Weapons Grade & $51-52^{\mathrm{c}}$ \\
\hline Low Enriched Uranium & $21-31,89^{\mathrm{a}}$ & Plutonium-239 Fuel Grade & $53-56^{\mathrm{c}}$ \\
\hline Medium Enriched Uranium & $32-33^{\mathrm{a}}$ & Plutonium-239 Reactor Grade & $57^{\mathrm{c}}$ \\
\hline Highly Enriched Uranium & $34-38^{\mathrm{a}}$ & Lithium-6 & $61-63^{\mathrm{d}}$ \\
\hline Very Highly Enriched U & $39^{\mathrm{a}}$ & Uranium-233 & $71-74^{\mathrm{e}}$ \\
\hline Plutonium-242 & $41-42^{\mathrm{b}}$ & Normal Uranium & 81 \\
\hline Americium-241 & 44 & Neptunium & 82 \\
\hline Americium-243 & 45 & Plutonium-238 & 83 \\
\hline Curium & 46 & Deuterium & 86 \\
\hline Berkelium & 47 & Tritium & 87 \\
\hline Californium & 48 & Thorium & 88 \\
\hline
\end{tabular}

a. Uranium enrichment - Nuclear Material MT Ranges

\begin{tabular}{|c|c|c|c|c|}
\hline NUCLEAR MATERIAL & MT & & t $\%$ U-23 & \\
\hline Depleted U & 11 to 18 & & & 0.7 \\
\hline riched U & 21 to 31,89 & 0.711 & $<\%$ & 5.0 \\
\hline hed U & & 5.00 & $<\%$ & 20.00 \\
\hline ed L & $34 \mathrm{t}$ & 20.00 & $<\%$ & 94.0 \\
\hline & & & & \\
\hline
\end{tabular}

b. Plutonium-242 Content - Nuclear Material MT Ranges

\begin{tabular}{lcccc} 
NUCLEAR MATERIAL & MT & \multicolumn{3}{c}{ Wt $\%$ Pu-242 Range } \\
Pu-242 & 41 & $20.0<\%$ Pu-242< 60.0 \\
Pu-242 & 42 & $60.0<\%$ Pu-242
\end{tabular}

c. Plutonium- 239 Content - Nuclear Material MT Ranges

$\begin{array}{lccc}\text { NUCLEAR MATERIAL } & \text { MT } & \text { Wt \% Pu-239/241 Range } \\ \text { Pu-239 Weapons Grade } & 51 \text { to } 52 & \% \text { Pu-240 }<7.0 \\ \text { Pu-239 Fuel Grade } & 53 \text { to } 56 & 7.0<\% \text { Pu-240 }<19.0 \\ \text { Pu-239 Reactor Grade } & 57 & 19.0<\% \text { Pu-240 }\end{array}$

d. Lithium-6 Content - Nuclear Material MT Ranges

\begin{tabular}{lcccc} 
NUCLEAR MATERIAL & MT & \multicolumn{3}{c}{ Wt \% Li-6 Range } \\
Li-6 & 61 & 7.56 & $\% \mathrm{Li}-6<$ & 55.0 \\
$\mathrm{Li}-6$ & 62 & 55.0 & $<\% \mathrm{Li}-6<$ & 80.0 \\
$\mathrm{Li}-6$ & 63 & 80.0 & $\% \mathrm{Li}-6$ &
\end{tabular}

e. Uranium-233 categories-Nuclear Material MT Ranges

$\begin{array}{lccr}\text { NUCLEAR MATERIAL } & \text { MT } & \text { ppm U-232 Range } \\ \text { U-233 } & 71 & \text { U-232 ppm }< & 5 \\ \text { U-233 } & 72 & 5<\mathrm{U}-232 \mathrm{ppm}< & 10 \\ \mathrm{U}-233 & 73 & 10<\mathrm{U}-232 \mathrm{ppm}< & 50 \\ \mathrm{U}-233 & 74 & 50<\mathrm{U}-232 \mathrm{ppm} & \end{array}$




\section{Table 2: Storage Study Milestones}

\section{MILESTONES}

\section{Complete}

- Storage Study Action Plan/Scoping Report NMP-92-07

Provided a report with the scope, work breakdown, and schedule for completing the Nuclear Materials Management Storage Study Report.

- Storage Study Questionnaire Design Meeting

Decided, and documented in the form of a Questionnaire, what information is required to provide a planning basis for nuclear materials storage for the next 50 years.

- Transmit Storage Study Questionnaire

Package included the final Questionnaire, bases and assumptions, and supplemental instructions agreed upon at the Questionnaire Design Meeting.

- Transmittal to Field Offices

Headquarters sent package with Questionnaire, etc. as well as format for transmittal of "electronic" data to the PSG.

- Established Site Contacts

$12 / 8 / 92$

$1 / 28 / 93$

Field Offices were surveyed for Site Contacts. Site Contacts were called to establish interfaces and answer questions.

- Questionnaire Responses

Sites developed information and transmitted responses (in form of disks, hard copy, or bcth) to their FO, DP-27, and PSG.

- Database Report NMP-93-7, Rev. 1

$6 / 18 / 93$

Predecisional draft and issued through SR FO to HQ.

- Database Report NMP-93-7, Rev. 1, Addendum 1

$6 / 30 / 93$ A supplement with LANL information was issued.

- Special Database Report NMP-93-12 Issued for headquarters use.

- Database Summary Report NMP-93-13

$9 / 1 / 93$

A condensation of 843 records from 70 sites based on storage concerns/issues, i.e. administrative, capacity, container, D\&D, disposition, form, Health Physics, RCRA, shipping, and inactive material issues and concerns.

- Nuclear Materials Storage Study

This report compiles previous draft reports and includes comments and additions received from participating Field Offices and DP-27 reviewers.

- Analysis and Follow-up Study

Conduct a study that addresses selected areas of concern identified during the initial analysis of the Storage Study Database. 
NMP-94-01

\subsection{ACRONYMS}

$\begin{array}{ll}\text { D\&D } & \text { Decontamination and Decommissioning } \\ \text { DOE } & \text { Department of Energy } \\ \text { DP } & \text { Defense Programs } \\ \text { EP } & \text { Extraction Procedure } \\ \text { LANL } & \text { Los Alamos National Laboratory } \\ \text { MT } & \text { Material Type (from DOE 5633.5) } \\ \text { NMMSS } & \text { Nuclear Materials Management and Safeguards System } \\ \text { ppm } & \text { Parts Per Million } \\ \text { PSG } & \text { Planning Support Group } \\ \text { RCRA } & \text { Resource Conservation and Recovery Act } \\ \text { RIS } & \text { NNMMSS Reporting Identification Symbols } \\ \text { SR } & \text { Savannah River Operations Office } \\ \text { SRS } & \text { Savannah River Site }\end{array}$




\section{APPENDIX}

- DP-27's Letter to Field/Operations Office

- Storage Study Questionnaire

- Questionnaire Design Meeting Attendees 


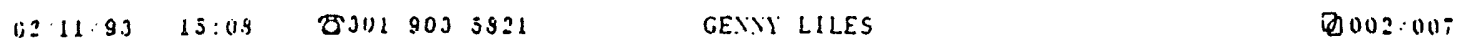
Doe fims Enis: (07.50)

\section{memorandum}

DATE: February 10, 1993

REPLY TO

ATN OF: DP -273

SUbuEct: Nuclear Materials Management (NMM) Study on the Storage of Nuclear Materials

To: A. E. Whiteman, Director, Weapons Quality Division, AL

T. A. Gradle, Acting Director, Safeguards and Security Division, $\mathrm{CH}$

R. J. Hansen, Assistant Manager for Site Operations, FERN

0 . L. Jones, Director, Safeguards and Security Division, ID

J. M. Penry, Director, Planning and Budget Division, OR

W. C. Rask, Director, Production Division, RF

J. E. Mecca, Director, Operations and Transition Division, RL

D. A. Ash, Director, Safeguards and Security Division, SF

J. D. Bilyeu, Director, Nuc. Materlals Mgmt. and Staff Support Office, SR

J. R. Bullian, Director, Safeguards and Security Division, PNR*

T. A. Bisnett, Director, Contracts Division, SNR*

*Thru: B. Demars, Deputy Assistant Secretary for Naval Reactors, NE-60

Along with the Westinghouse Savannah River Company (WSRC) Planning Support Group (PSG), we conducted a meeting on January 27 and 28, 1993, at the Department of Energy (DOE) Headquarters (HQ). regarding the Complexwide NMM Study on the Storage of Nuclear Materials. Representatives from DOE $H Q$, field offices, and Government-owned contractor-operated facilities were in attendance to discuss the study scope and plan and finalize the straman questionnaire. As a result of this meeting, a finalized study scope and plan and strawman questionnaire were mutualiy agreed upon and documented.

The Headquarters-approved MM storage study questionnaire (Attachment 1) is being provided to you for completion as agreed upon during the $H Q$ meeting. If you have any questions or concerns regarding Attachment 1 , please contact G. W. Becker (WSRC PSG) at 803-725-5516 for clarification.

All responses to the questionnaire should be provided to me with a copy to the PSG by March 10, 1993. Responses should be provided on disk in American Standard Code for. Information Interchange (ASCII) format. Reporting in a common format allows for the data to be compiled and processed in a timely manner. With the abundance of information to be provided and a scheduled completion date of May 1993, providing the information in ASCII format will be most efficient.

Your cooperation and assistance are solicited for the timely completion of this task. If you have additional questions or need additional 
information on this, please contact me (301-903-2402) or have your staff contact $\mathrm{J}$. Olencz (301-903-6018) of my staff.

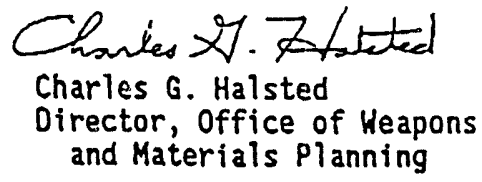

Attachment

Cc:

J. A. Ford, DP -63

R. D. Hahn, DP-64

K. P. Ferlic, DP -65

A. Cygelman, DP-42

G. Werkema, $\mathrm{AL}$

R. N. Nolan, SF

R. J. Spence, OR

G. M. Nichols, SR

W. D. Clark, SR

G. W. Becker, HSRC 


\section{NUCLEAR MATERIALS MANAGEMENT: STOR.AGE STUDY QUESTIONNAIRE}

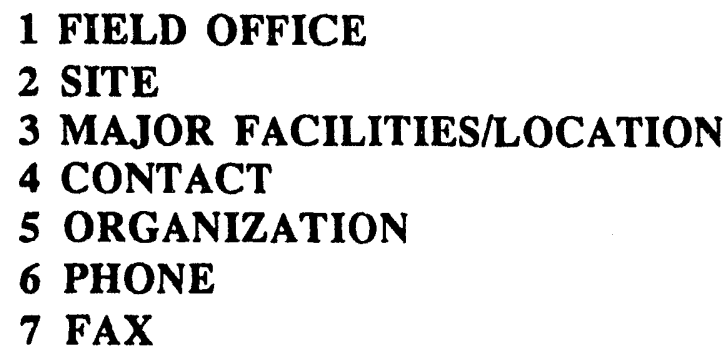

\begin{tabular}{|c|}
\hline Question no. 1 \\
\hline Question no. 2 \\
\hline Question no. 3 \\
\hline Question no. 4 \\
\hline Question no. 5 \\
\hline Question no. 6 \\
\hline Question no. 7 \\
\hline
\end{tabular}

Attached is a sample questionnaire form to be used by Field Offices and Sites (FO/Sites) to provide information to the Planning Support Group (PSG). The basis/assumptions for completing this questionnaire are:

A. Each FO/Site shall include all DOE Order 5660.1A reportable material in inventory as of September 30, 1992. Oak Ridge FO/Sites shall include natural and depleted lithium. Spent fuel which is included in Environmental Restoration and Waste Management's EIS is excluded from the survey.

B. The questionnaire will provide a Complex-wide planning basis for nuclear material storage considerations for the next 50 years (interim).

C. Sites should complete items 1-4 for each site MT and specific material group.

D. In items 1-4, each FO/Site should report on materials located/stored at their site, regardless of programmatic responsibility for the material to the extent that information is available.

E. Each FO/Site should use its best judgment to determine logical or functional grouping/consolidation of material types (MT). Site specific material groups must be traceable to NMMSS COEI (Composition of Ending Inventory) quantities. Provide a unique "site-specific material group identification code" for study data handling, reporting and processing.

F. Each FO/Site shall complete item 5, "Storage Capacity," as a single comprehensive narrative describing current and future storage conditions at the site.

G. The FO/Site programmatically responsible for material stored at another site should include discussion of this material under item 5 .

H. WSRC-PSG is available for clarification and assistance regarding completion of the questionnaire. Please expedite transmittal of completed questionnaire forms to WSRC-PSG* as they become available.

I. Completed questionnaires are to be provided to DP-273 with a copy sent to the PSG. DP-273 will receive a copy of all correspondence between FO/Sites and WSRC-PSG.

* George. W. Becker, Jr.

Planning Support Group

Westinghouse Savannah River Company

Building 773-41A, 130

P. O. Box 616

Aiken, SC 29802

(803) $725-5516$

(803) $725-2978$ (Fax)
* Jack L. Jarriel (Alternate)

Planning Support Group

Westinghouse Savannah River Company

Building 773-41A, 159

P. O. Box 616

Aiken, SC 29802

(803) $725-5476$

(803) 725-2978 (Fax) 


\section{NUCLEAR MATERIALS MANAGEMENT: STORAGE STUDY QUESTIONNAIRE Site Specific Material Group Code \\ no. 8}

1. Material Type Indicare the material type name(s) Question no. 9 and associated NMMSS material type number(s) (MT)

no. 10 . 2. Site Specific Material Grouping

What are the common name(s) for the items in this site specific material group Question no. 11

Describe your basis for grouping these items, e.g., common physical and chemical form, managed in the same manner, etc.

Describe your basis or guestion no. 12

\section{Material Description}

Provide the site Item Description Codes (IDC) or equivalent, descriptive Provide information on the chemical con

narrative, and the corresponding NMMSS

Inventory code (COED) that identify items.

Question no. 14
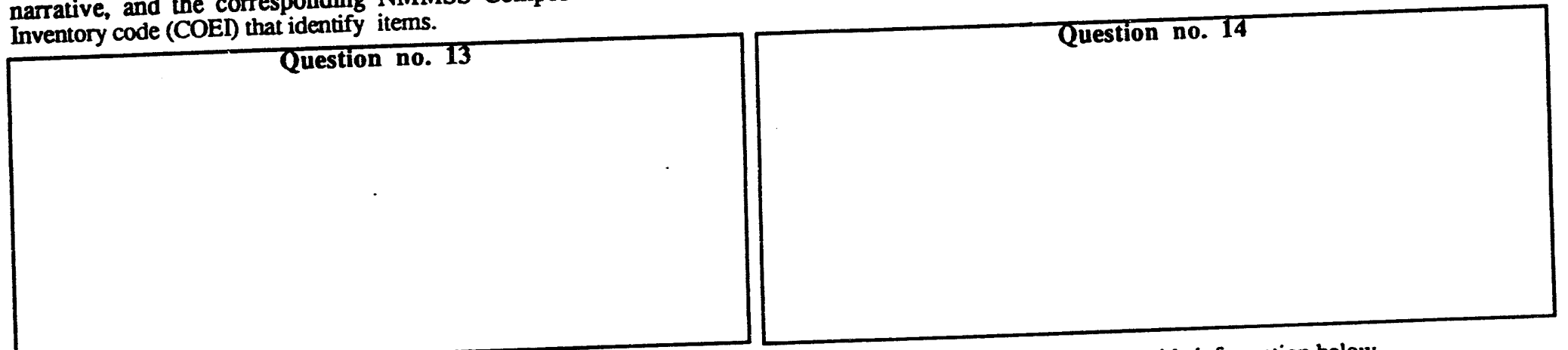

Do any of these materials exhibit any RCRA hazardous characteristics or contain any listed constituents? If so provide information below.

Question no. 15

\begin{tabular}{ll}
\hline & \\
Provide the total quantity of material & Question no. 16 and the quantity of material in a typical storage package \\
in this site specific material grouping.
\end{tabular}


NUCLEAR MATERIALS MANAGEMENT: STORAGE STUDY QUESTIONNAIRE

Site Specific Material Group Code

\section{Storage Containers}

Describe current material packaging.

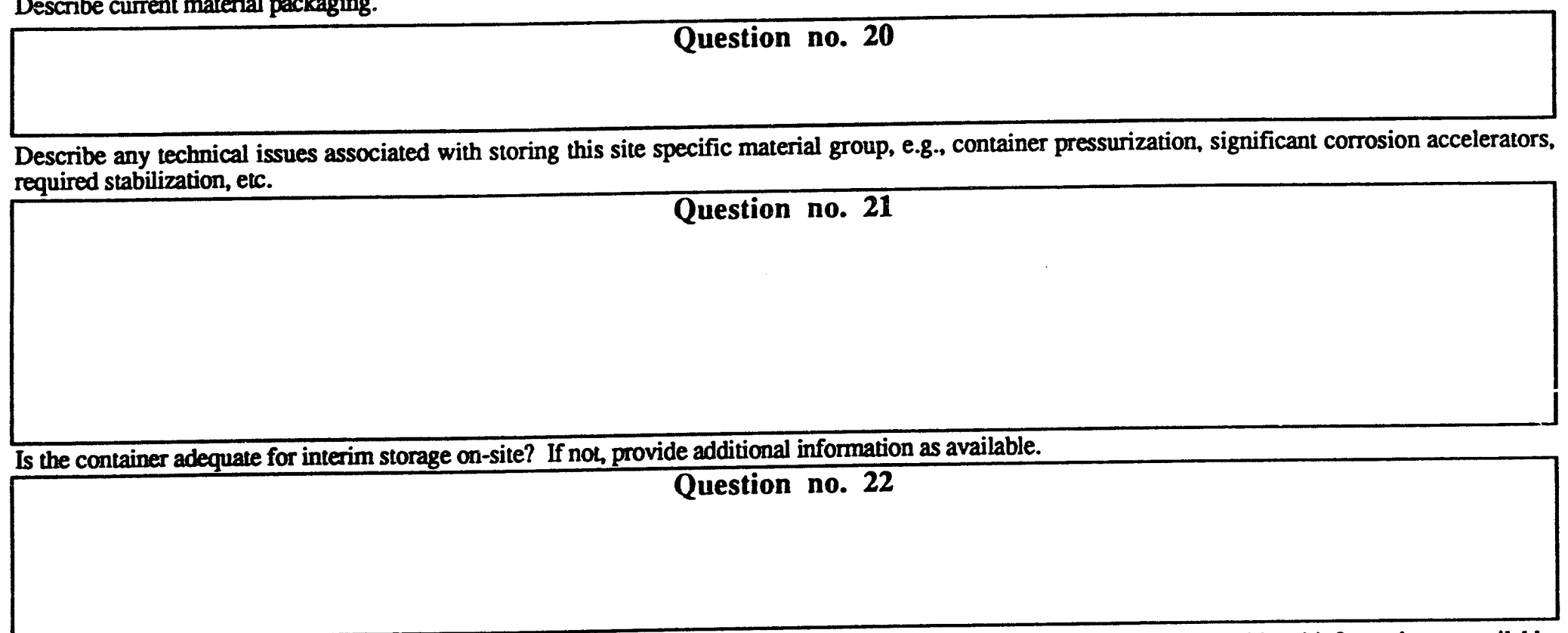

Can this material be shipped? $\square$ As-is $\square$ Needs overpacking $\square$ Needs repackaging $\square$ Other (e.g. requires treatment etc.) Provide additional information as available.

Question no. 24


-

\section{NUCLEAR MATERIALS MANAGEMENT: STORAGE STUDY QUESTIONNAIRE}

5. Storage Capacity ent inventory, will there be any excess/shortfall in in regulatory and DOE Order requirements, proposed shipments, facility

program plans, facility plans, and other information (such as technical issues, regulatory and programmatic responsibility of your site.
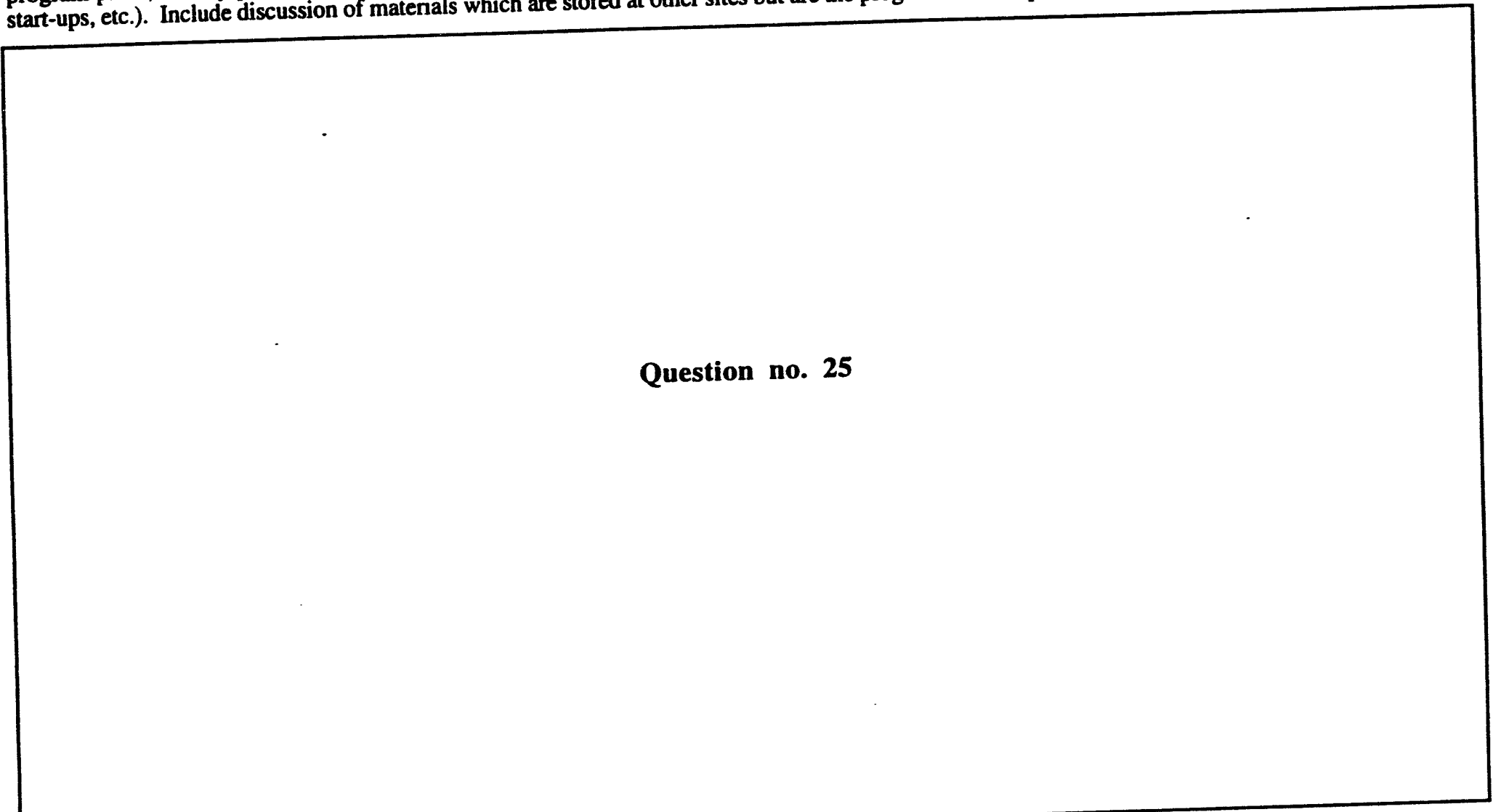
Table 1. Nuclear Material Management: Storage Study Contact Matrix

\begin{tabular}{|c|c|c|c|c|}
\hline SITE & ORG. & NAME & TELEPHONE & FAX \\
\hline \multirow[t]{4}{*}{ Albuquerque } & Field Office & J. A. Baca & $505-845-5391$ & $505-845-4722$ \\
\hline & & X Lawerence Barela & $505-845-6228$ & \\
\hline & & C. A. Cruz & $505-845-4282$ & $505-845-5188$ \\
\hline & LANL & Sherry Sanes & $505-665-2712$ & \\
\hline \multirow[t]{3}{*}{ Chicago } & Field (ffice & C. G. Ahlberg & $708-252-2068$ & $708-252-2078$ \\
\hline & & F. A. Healy & $708-252-2827$ & $708-252-2078$ \\
\hline & & A. J. Traina & $708-252-3827$ & $708-252-2078$ \\
\hline \multirow[t]{3}{*}{ Fernald } & Field Office & Ray Hansen & $513-738-9287$ & $513-738-9236$ \\
\hline & FEMCO & Shirley Kaushiva & $513-738-6239$ & $513-738-9521$ \\
\hline & & Jim Lewis & $513-738-6812$ & $513-738-9507$ \\
\hline \multirow[t]{8}{*}{ Headquarters } & DP-2;3 & $\mathrm{X}$ Ray Cooperstein & $301-903-5353$ & $301-903-5821$ \\
\hline & & X Bill Newton & $301-903-2975$ & $301-903-5821$ \\
\hline & & X Joe Olencz & $301-903-6018$ & $301-903-5821$ \\
\hline & DP-634 & X Dave Bivans & $301-903-5909$ & $301-903-6282$ \\
\hline & NE-60 & X Richard MacClary & $703-602-1663$ & \\
\hline & DP-27/ETM & $\mathbf{X}$ James Behrend & $301-903-2765$ & \\
\hline & DP-27/MMES & X Trygue Myhre & $301-903-2830$ & $301-903-5821$ \\
\hline & DP-27/WSRC & X Randy Yourchak & $301-903-2753$ & $301-903-5821$ \\
\hline \multirow[t]{2}{*}{ Idaho } & Field Office & $\mathrm{X}$ Audrey D. Anderson & $208-526-5903$ & $208-526-5903$ \\
\hline & & M. M. Brower & $208-526-5918$ & $208-526-0270$ \\
\hline Nevada & Field Office & Bob Ramsted & $702-295-0082$ & \\
\hline \multirow[t]{4}{*}{ Oak Ridge } & Field ()ffice & $\bar{X}$ Becky Eddy & $615-576-4119$ & $615-576-8010$ \\
\hline & & X Tom Wynn & $615-576-0630$ & $615-576-5401$ \\
\hline & MMES & X Gary F. Hagan & $615-574-3695$ & $615-574-9044$ \\
\hline & & $\mathrm{X}$ James D. Stout & $615-574-2119$ & $615-576-4760$ \\
\hline Pittsburgh Naval Reactors & Field Office & E. A. Evosevic & $412-476-7248$ & $412-476-7310$ \\
\hline \multirow[t]{6}{*}{ Richland } & Field Office & Suzanne Clark & $509-376-9055$ & $509-376-0695$ \\
\hline & & X R. L. Leo Guillen & $509-376-4762$ & $509-376-0695$ \\
\hline & & D. W. Templeton & $509-376-2966$ & $509-373-1952$ \\
\hline & WHHCO & Luis Gonsales & $509-373-3541$ & \\
\hline & & Russ Hulvey & $509-376-4407$ & \\
\hline & & X Bob Salley & $509-372-3571$ & \\
\hline \multirow[t]{4}{*}{ Rocky Flats } & Field Office & S. L. Rudolph & $303-966-5788$ & $303-966-5857$ \\
\hline & & J. D. Steward & $303-966-4873$ & $303-966-5857$ \\
\hline & EGG & X Scott H. Davies & $303-966-7336$ & \\
\hline & KMI & X Richard Harris & $303-966-3121$ & \\
\hline San Francisco & Field Office & D. G. McIntosh & $510-423-4717$ & $510-422-6306$ \\
\hline \multirow[t]{6}{*}{ Savannah River } & Field Office & X William D. Clark & $803-725-5566$ & $803-725-8816$ \\
\hline & & N. Khalil & $803-725-5572$ & $803-725-8816$ \\
\hline & WSRC PSG & X George W. Becker, J. & $803-725-5516$ & $803-725-2978$ \\
\hline & & X Jack L. Jarriel & $803-725-5476$ & $803-725-2978$ \\
\hline & & X Robert E. Meadors & $805-725-5431$ & $803-725-2978$ \\
\hline & WSRI: & X Blaine K. Taylor & $803-725-5349$ & $803-725-2978$ \\
\hline Schenectady Navel Reactors & Field Office & C. Bowie & $518-395-6373$ & $518-395-6390$ \\
\hline
\end{tabular}



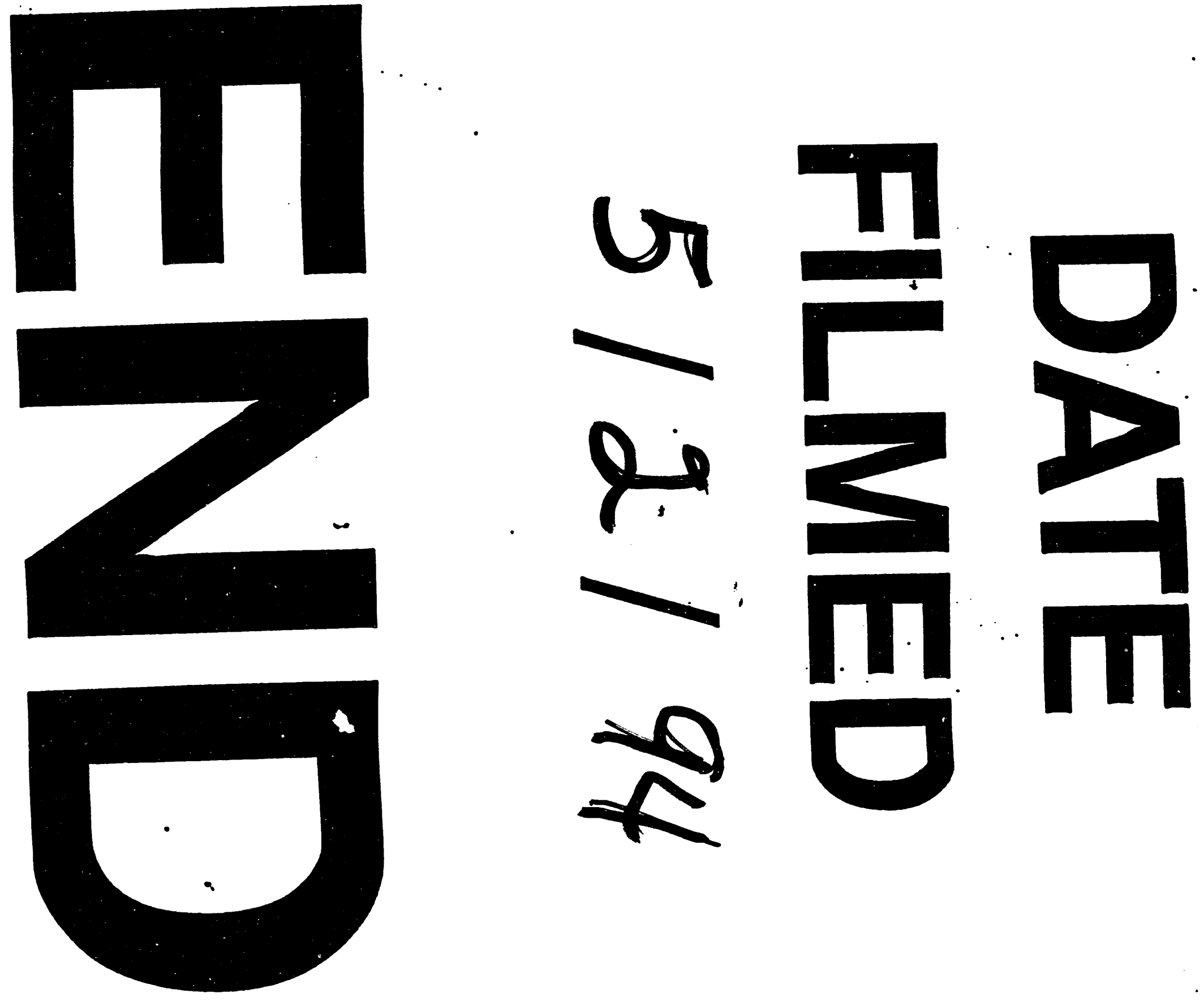
